\title{
CRITICAL PERSPECTIVES IN ENGLISH FOR ACADEMIC PURPOSES: EXPERIENCES IN THE LANGUAGE WITHOUT BORDERS PROGRAM
}

\author{
PERSPECTIVAS CRÍTICAS NO ENSINO DE INGLÊS \\ PARA FINS ACADÊMICOS: EXPERIÊNCIAS NO \\ PROGRAMA IDIOMAS SEM FRONTEIRAS
}

Cristiane Carvalho de Paula Brito ${ }^{1}$

[https://orcid.org/0000-0002-7210-6635]

Jéssica Sousa Borges ${ }^{2}$

[https://orcid.org/0000-0001-5087-7511]

Lucas Figueiredo Martins ${ }^{3}$

[https://orcid.org/0000-0002-9963-063]

DOI: 10.30612/raido.v15i37.14547

\begin{abstract}
In this paper, we aim to reflect upon critical perspectives in the teaching of English for Academic Purposes (EAP), by discussing some didactic proposals developed by teachers participating in the Language Without Borders Program (LwB). The program attempts to contribute to the process of internationalization of Brazilian universities by offering linguistic support to the academic community as well as a field for teacher education. Our view of criticality is based on the theoretical scope of the Bakhtin Circle, which conceives language as a social-historical, dialogic and situated practice, permeated with power relations. From a qualitative methodological approach, we focused on the lesson plans and materials produced for the classes as well as fieldnotes to investigate the proposals for two courses on oral production, whose objectives were to prepare students to create and deliver oral presentations in the academic context. Criticality was developed in the courses by problematising accessibility and inclusion in oral presentations and a hegemonic view of language itself. Our reflection may contribute to the development of EAP material and teaching practices.
\end{abstract}

Keywords: English for academic purposes; criticality; teaching.

RESUMO: Neste artigo, pretendemos refletir sobre perspectivas críticas no ensino de inglês para fins acadêmicos(IFA), discutindoalgumas propostas didáticas desenvolvidas

1 Universidade Federal de Uberlândia (UFU). Doutora em Linguística Aplicada pela UNICAMP. Professora Associada, Instituto de Letras e Linguística. E-mail: cristiane.brito@ufu.br.

2 Universidade Federal de Uberlândia (UFU). Mestranda no Programa de Pós-graduaçăo em Estudos Linguísticos. E-mail: jesccp7@gmail.com.

3 Universidade Federal de Uberlândia (UFU). Licenciando no Curso de Letras: Inglês e Literaturas de Língua Inglesa. E-mail: f.lucas.m@gmail.com. 
por professores participantes do Programa Idiomas Sem Fronteiras (IsF). O programa tenta contribuir para o processo de internacionalizaçăo das universidades brasileiras, oferecendo apoio linguístico à comunidade acadêmica, bem como um campo para a formaçăo de professores. Nossa visăo de criticidade se baseia no escopo teórico do Círculo de Bakhtin, que concebe a linguagem como uma prática sócio-histórica, dialógica e situada, permeada por relaçôes de poder. A partir de uma abordagem metodológica qualitativa, focamos nos planos de aula e materiais produzidos para as aulas, bem como nas notas de campo, a fim de investigar as propostas para dois cursos sobre produçăo oral, cujos objetivos eram preparar os estudantes para criar e apresentar comunicaçôes orais no contexto acadêmico. A criticidade foi desenvolvida nos cursos por meio da problematizaçăo da acessibilidade e da inclusăo nas apresentaçôes orais e de uma visâo hegemônica da própria língua. Nossa reflexăo pode contribuir para o desenvolvimento de material didático e para as práticas pedagógicas no âmbito do IFA.

Palavras-chave: Inglês para fins acadêmicos; criticidade; ensino.

\section{INTRODUCTION}

English for Academic Purposes (EAP), a sub-field of English for Specific Purposes (ESP), has long been seen as an area which develops and researches courses aimed at preparing students to face the demands of academic life in English speaking academic environments. Traditionally, it involves the teaching of the four main skills (listening, reading, speaking and writing) as well as of the conventions and cultural codes embedded in different contexts and which may influence students' academic success. More recently though, works based on critical studies have problematized what could be considered an 'accommodationist' or a mere pragmatic view of EAP.

Taking this into account, in this paper, we aim to reflect upon critical perspectives in EAPs, by discussing the literature in the realm and some teaching proposals developed by teachers ${ }^{4}$ participating in the Language Without Borders Program. To understand the context in which the EAP teaching proposals were developed, we start by making some considerations on two important Brazilian programs implemented by the federal government, namely: Science without Borders (SwB) and Language without Borders (LwB) itself.

The first one, implemented in 2011, focused on providing international mobility for higher education students and aimed at promoting the internationalization of Brazilian science and technology. Its fields of interest were mostly STEM fields (Science, Technology, Engineering and Math). In the institutional website of $\mathrm{SwB}^{5}$, one reads that

Science without Borders is a large-scale nationwide scholarship program primarily funded by the Brazilian federal government. The program seeks to strengthen and expand the initiatives of science and technology, innovation and competitiveness

\footnotetext{
4 The term 'teacher' is used here to refer to pre-service teachers, who attended a Language Teacher Education Program and received a scholarship to participate in LwB.

5 http://www.cienciasemfronteiras.gov.br/web/csf-eng/faq
} 
through international mobility of undergraduate and graduate students and researchers. The program is a joint effort of the Ministry of Education (MEC) and the Ministry of Science and Technology (MCT) through their respective funding agencies - CAPES and CNPq.

With the implementation of SwB, the low English proficiency among students (specially the undergraduate ones) became evident and, in 2012, the Brazilian federal Government implemented the Language without Borders Program (LwB) ${ }^{6}-$ at this time with the name of English without Borders - in order to offer linguistic support to students participating in $\mathrm{SwB}^{7}$, contributing to the process of internationalization as well as offering a field for teacher education.

Present in almost all federal universities in Brazil and in some state ones, LwB offered proficiency tests and language courses in different languages (English, French, Italian, Spanish, Portuguese as a Foreign Language, German and Japanese), most of them with focus on specific purposes. Classes were taught by undergraduate or graduate students who received a scholarship and were supervised by pedagogical coordinators.

Teachers at LwB could participate at most two years in the program and should develop a 20-hour-weekly schedule, in which they had to perform activities such as: attend pedagogical and administrative meetings with the coordinators; dedicate 12 hours to teaching; offer face-to-face or online tutoring for their students; plan classes and develop teaching material; proctor proficiency tests; attend and deliver lectures; get involved in actions related to the process of internationalization of university, among others. In previous work, we discussed how LwB has become a space of pedagogical residency for pre-service teachers as it allows them to experience, in the early years of their undergraduate program, "the complex dynamics of the teaching practice, so as to build their professional identity, which is always fluid and moving and always open to reconstructions" (BRITO; CÓRDULA, 2020, p. 34)8.

Regarding the courses offered by $L w B$, most of them focused on specific purposes, especially the academic ones. The program had a range of courses, divided by levels ( $\mathrm{A} 1$ to $\mathrm{C} 1$ according to the Common European Framework of Reference for Languages) and duration, offered nationally by each local Language Center ${ }^{9}$ (LC), such as: Reading Comprehension: Abstracts, Reading Comprehension: Papers, Oral Comprehension: Lectures and Classes, Oral Production: Academic Interactions, International Academic Mobility: First Steps, Oral Production: Interviews, Cultural Differences, TOEFL ITP: Strategies, English for Specific Purposes: Engineering, English for Specific Purposes: Law, Oral Production: Debates, English as a Medium

6 Find the official website of the program in http://isf.mec.gov.br/

7 Due to its high costs and uncertain benefits, SwB was cancelled in 2017, although its funding had already been suspended in 2015. Nearly 100,000 Brazilian scholarships for studies abroad were funded by this program.

8 Our translation from the original: "a complexa dinâmica do fazer docente, construindo, pois, sua identidade profissional, a qual será sempre fluida e movente e sempre aberta a reconstruçôes" (BRITO; CÓRDULA, 2020, p. 34).

9 The institutions participating in LwB had a Language Center formed by administrative and pedagogical coordinators and the teachers. 
of Instruction for Professors, Writing: Abstracts, Writing: Paragraphs, English Varieties etc. The authors of this paper worked respectively as the pedagogical coordinator and English teachers in a LwB LC in a public university in Minas Gerais from 2017 to 2020.

In terms of organization, besides this introduction and some final remarks, we start by pointing out some criticisms against EAP; then we make some considerations on the tenets of critical EAP and discuss how such perspectives may find a place in EAP classes. Following, we discuss some teaching proposals developed by the last two authors of the paper while they participated as teachers in LWB.

\section{CRITICISMS AGAINST EAP}

In this section we aim to highlight some criticisms that have been attributed to EAP throughout the years. Considering that our practice should be sensitive to a broader social and political context and that it is not restricted to the classroom environment, we find it important for those who work in the area to be aware of the different voices and positions scholars have concerning the teaching of EAP.

According to Helmer (2013), "one might argue that 'pragmatic' EAP characterizes most if not all 'standard' EAP approaches that aim to prepare students for target-situation demands" (HELMER, 2013, p. 274). Indeed much of the criticism against EAP concerns its 'ideology of pragmatism' - the very idea that EAP is not concerned with social and political aspects that involve the teaching processes.

Pennycook (1994) is one of the first scholars to respond to such criticism by problematizing EAP's theory of language. In a seminal paper, entitled Beyond (F) utilitarianism: English "as" academic purpose (1994), he mentions two challenges faced by courses in EAP. The first challenge concerns the content of EAP courses, which are commonly seen as futile and not really meaningful, regardless their specificity. Although EAP courses open space to academic content, it may only serve as a pretext to communicate or as a medium for language learning. The second challenge refers to the role of EAP courses as a form of service industry to their institution, as if EAP courses were based on the principle of utilitarianism (they would exist only to serve institutions): as if they were made to achieve certain goals, regardless contextual, cultural, political aspects of language teaching. Putting those two terms together (considering the criticisms that EAP would be both futile and utilitarian), Pennycook coins the term 'futilitarianism' to refer to the biggest challenge faced by EAP courses.

Pennycook goes on saying that the challenges he mentions are related to some beliefs. The belief that English is a neutral medium to achieve academic purposes and the belief that English (or any language) is a medium through which meanings are expressed (PENNYCOOK, 1994, p. 13). These beliefs are based on the idea that there is a divide between language and content and they consolidate what could be called an 'accommodationist ideology' in EAP, which conveys the idea that students are supposed to uncritically assimilate academic life. Students are the ones who should change/adapt to fit into the academic culture. This ideology simply does not question the status quo of institutional/academic practices. 
If this accommodationist ideology is not questioned and we just keep preparing EAP students to 'enter'/to be accepted into academic or professional life, it may, in Helmer's words, "result in the maintenance of hierarchical and unequal power distributions that perpetuate assimilationist values that homogenize linguistic and cultural diversity" (HELMER, 2013, p. 274). Therefore, based on this kind of discussion, many scholars have been advocating the need to resist the ideology of pragmatism and the accommodationist ideology (PENNYCOOK, 1994; BENESCH, 2009, 2001; CHUN, 2009; HARWOOD \& HADLEY, 2004; EDGE, 2006). Pennycook (1994), for instance, claims that a pragmatist approach may do a pedagogical disservice to the students. If students are only taught academic and linguistic skills, how - Pennycook asks - will they develop linguistic, social and cultural criticism to understand and question the way language works inside and outside educational institutions, for example?

Besides that a very strong argument brought by Pennycook (1994) is that if we do not take into consideration the political and ideological contexts of language education, EAP field may itself end up being seen as a mere service department and it would not strengthen our position as teachers and researchers. Taking this into account, the author defends a proposal: he points out that English for academic purposes implies a notion of language as a neutral vehicle for transporting academic content. According to him, it promotes a theory of language as an innocent and transparent medium through which academic purposes could be achieved. Pennycook's counter proposal is English as academic purposes. The shift from for to as emphazises English itself, it highlights the politics of English, suggesting "a critical stance that recognizes the ways in which English is embedded in social, cultural, and political relations" (PENNYCOOK, 1994, p. 14).

The challenge, therefore, is how to develop a more critical form of EAP, one that would not see itself as a service industry to other departments or have as its goal the assimilation of students into academic culture. A more critical approach of EAP would consider students and teachers as agents of the whole process of teaching and learning. Moreover, it would also be concerned with providing strategies to resist neoliberal discourses on which second language learning, especially English, has long relied (CHUN, 2009). That is what we discuss in the next section.

\section{CRITICAL PERSPECTIVES IN EAP: IMPLICATIONS FOR TEACHING}

This brief overview of some criticisms against EAP sheds light on the history and discussions that are involved in the field. Starfield (2013) says that it is within the sub-field of EAP that most of the research on criticality has been carried out so as to investigate how students acquire the academic literacies demanded by Western higher education institutions. She argues that studies have investigated how dominant institutional discourses position students as second-language speakers, by failing "to recognize the discourses the students bring with them from their homes or previous literacy practices" (p. 467).

Having said that, we now discuss some principles that constitute what could be considered to be a more critical perspective of EAP and point out some implications 
for teaching. We begin by discussing the very notion of language, which, in our view, is what underpins the approaches that guide teaching principles and practices.

In a more traditional/structuralist view of language, scholars try to relate linguistic structures to social structures. Although they assume the relation between language and social or cultural structures, they are still seen as separate things. On the other hand, on what could be considered a critical perspective - and of course the term 'critical' itself could also be discussed by many different perspectives - language is seen as a social practice in which one does not try to just correlate language and society; instead language is seen as already/always social and cultural. That is to say that language is not a medium through which meaning is conveyed - it is through and in the language that we position ourselves as subjects in the world. Language as a social practice is also about considering that enunciation is always a situated, concrete and unique act.

Starfield (2013) says that, although the term 'critical' may include the work of different scholars (such as Freire, Foucault, Bourdieu, Said, the theorist from the Frankfurt School, among others), studies concerned with critical perspectives

share a concern with how unequal power relations shape interaction and opportunity both in and outside of the classroom; with how identities of learners and teachers are shaped by discourse, by unequal access to resources for meaning making, and by broader social inequity, along with a commitment to promoting social justice and change (STARFIELD, 2013, p. 462).

Pennycook (1994), when studying English teaching in Hong Kong, states that, in this context, English was seen as a language already full of colonial, racial, class and gendered assumptions. In other words, there is no way to erase/obliterate the historicity of English or of any language in the process of teaching them. That is why this author mentions the need to de-colonize words. De-colonisation of words is about providing language practices in which students could find ways to explore English, by, for example, resisting hegemonic discourse. In this sense English could be seen as a tool of subversion.

We should highlight that critical perspectives could start in the initial stages of language learning. In other words, we refuse the belief that first we teach language then we propose critical perspectives as if languages were a mere code in which speakers could 'deposit' their ideologies, histories, cultures and so on. We recognise however that such a position is only possible to be sustained when considering language in its broader aspects.

Bringing these reflections to our own context, we can say that, in many of the EAP courses taught at LwB, we had to deal with contradictions, resistance and conflictive representations of what it is like to learn English in Brazil. Considering the courses we taught, we had to take into consideration the need to allow students to understand the functioning of language through real texts and communicative events. When teaching writing (a course on the writing of essays, for example), would it be enough to provide students with a list of techniques with no relation to the actual contexts in which such writing may take place?

The answer is 'no' if we agree with Bakhtin, when he claims that "we know our native language - its lexical composition and grammatical structure - not from dictionaries 
and grammars but from concrete utterances that we hear and that we ourselves reproduce in live speech communication with people around us" (BAKHTIN, 1935/1986, p. 78). Although referring to a mother tongue, Bakhtin's view points to the fact that teaching a language as a decontextualized process that focuses only on the structural components of the target language (on its phonological, lexical, morphological and syntactic levels) and promotes no connections with students' social world does not seem to be a fruitful work.

Also according to Bakhtin and his Circle, "each utterance is filled with echoes and reverberations of other utterances to which it is related by the communality of the sphere of speech communication" (BAKHTIN, 1935/1986, p. 91). This statement points to one of the most important notions in the bakhtinian theory, which is the notion of dialogism. It means that utterances always refer to other utterances, which makes language a huge thread of meanings. If we accept the dialogic nature of language we see how important it is to provide language practices in which students can work with reverberations, with the echoes of other utterances, because when we hear the echoes, we have something to say, we have a 'counter-word' in bakhtinian terms.

Besides we can state that a word (a text, an image etc) that means almost nothing to one reader may be totally meaningful to another. If we are teaching an academic writing course, we could, for instance, explore activities using different papers or abstracts according to the academic areas of our students. Students could read and paraphrase an abstract or a paper chosen by themselves, having thus the chance to approach a text that means something to them. In short, this way they could have better chances to achieve their goals and this kind of activity could also help teachers deal with different levels as it focuses on the language practice not on grammar or the text itself.

Another important concept from Bakhtin and his Circle refers to the concept of word itself. Vološinov claims that

we never say or hear words, we say and hear what is true and false, good or bad, important or unimportant, pleasant or unpleasant, and so on. Words are always filled with content and meaning drawn from behavior or ideology (VOLOŠINOV, 1929/1973, p. 70).

Saying that we do not hear words means that, whenever we enunciate (or hear/ write) something, we evoke memories, meanings, historicity. It means that a word is never neutral and that "the word is the ideological phenomenon par excellence" (VOLOŠINOV, 1929/1973, p.13).

Let us take the word 'inequality' to give an example. When we google 'inequality' (or any other word), we find different images related to it, as the ones below in Fig. 1. 
Fig. 1

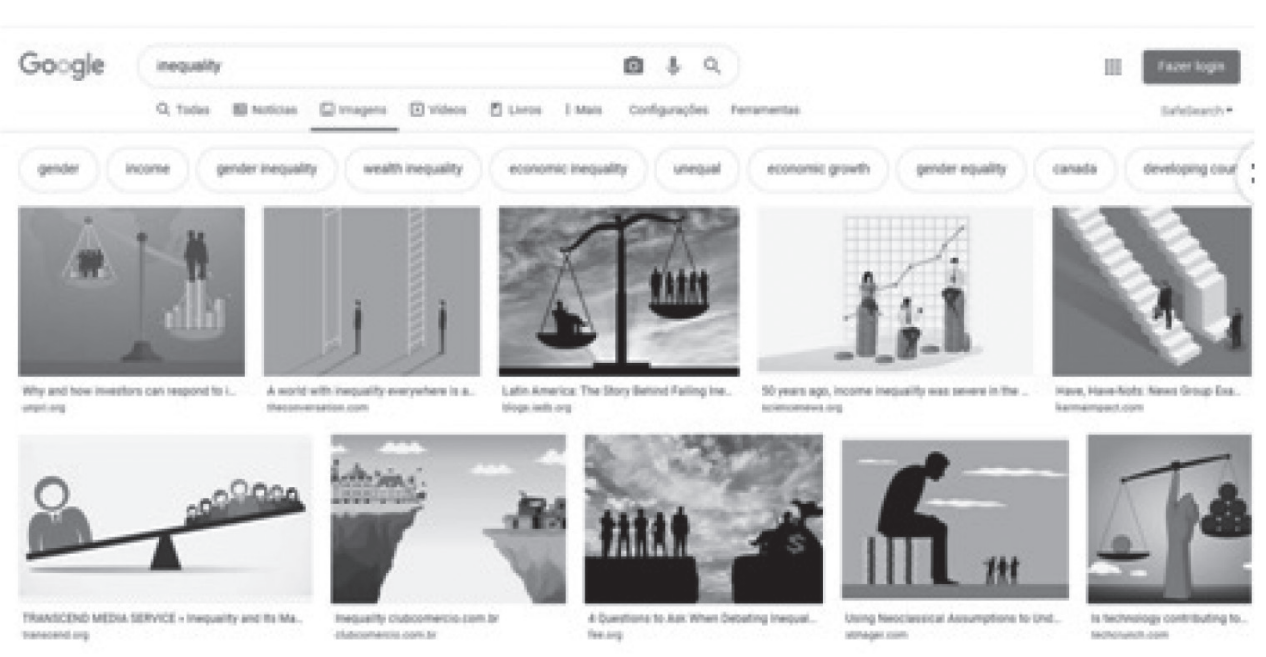

Source: Google ${ }^{10}$

By doing it, we can explore with students what comes first on search engines on the web and then promote a good discussion in terms of the non neutrality of the virtual environment and the ways it moulds or frames how we see the world. Noble (2018), for instance, discusses how algorithms "reinforce oppressive social relationships and enact new modes of racial profiling" (p.1), by investigating different forms of technological redlining. According to her,

On the Internet and in our everyday uses of technology, discrimination is also embedded in computer code and, increasingly, in artificial intelligence technologies that we are reliant on, by choice or not. I believe that artificial intelligence will become a major human rights issue in the twenty-first century. We are only beginning to understand the long-term consequences of these decision-making tools in both masking and deepening social inequality. (NOBLE, 2018, p. 1)

Another example we find in Benesch (2006), who works with critical media awareness (CMA). She claims that "critical media literacy skills are as valuable to English language learners (ELLs) as the more traditional academic skills taught in EAP courses" (p. 50). This is due to the fact that CMA covers skills that are useful to English language learners as they are supposed to engage not only on academic life but also on family, social, and work lives. Such engagement would make it possible for students to understand and participate "not only in academic life but also in public issues that affect them directly, such as educational funding, immigration policy, testing and employment trends" (BENESCH, 2006, p. 50) ${ }^{11}$.

10 https://www.google.com.br/search?q=inequality\&sxsrf=ALeKk00DNx6k09vPvSM9Zo N4Hek8qyBi3A:1592427711552\&source=lnms\&tbm=isch\&sa=X\&ved=2ahUKEwiX9M7A34nqAhVL GLkGHaK nAU4Q_AUoAnoECBIQBA\&biw=1366\&bih=635\&sfr=vfe Acess 18 June 2020.

11 Benesch (2006) points out some questions that could be asked and explored when approaching reports or broadcasts, for instance: what is being highlighted and downplayed?; how are members of various groups and the activities in which they engage referred to and what do these references say about the ideology of the author and source?; is the report featured in the front page?; who is quoted in the article or broadcast, and how much space or air time they are allowed? 
In previous works, Benesch (1999) explores the distinction between 'needs analysis' (which is one of the tenets of ESP and widely used to determine curriculum design) and 'rights analysis'. Her point is that 'needs' is a psychological term with a biological connotation and it naturalizes what is socially constructed. Needs are assumed to be beneficial to students, so there is no place for negotiation as there seems to be no conflict in the relation between students and institutions. 'Rights', on the other hand, is political and negotiable and

recognizes the classroom as a site of struggle. It studies how power is exercised and resisted in an academic setting, aiming to reveal how struggles for power and control can be sources of democratic participation in life both in and outside the classroom. (BENESCH, 1999, p. 315)

Benesch claims that rights should not be seen as a set of pre-existing demands rather it is a conceptual framework for questions about power and resistance. Kubota and Chiang (2013) corroborates Benesch's view in a work in which they discuss how categories such as gender and race are conceptualized in second language education and sociolinguistics. They argue that

in the discourse of needs analysis, learners are viewed as individuals with varied levels of discrepancy between their linguistic or professional knowledge/skill and the target needs. However, in performing certain skills, what learners actually experience in a specific discipline or profession might differ depending on their individual attributes such as gender, race, class, nationality, accent, age, religion, and sexual identity (KUBOTA; CHIANG, 2013, p. 483).

In other words, more than enabling students to fulfill academic requirements, critical EAP seeks to help them "articulate and formalize their resistance, to participate more democratically as members of an academic community and in the larger society" (BENESCH, 2001, p. 57). For this language cannot be seen as transparent, neither can texts be treated as 'given artifacts' once enunciative processes are always embedded in socio-ideological relations of power.

We now discuss some teaching proposals developed in the context of LwB and which attempted to develop a critical perspective of EAP. We highlight however that the proposals do not intend to offer a model of how to teach, rather our aim is to problematize how a particular experience may contribute to develop an 'EAP practice' more sensitive to a view of language as constitutive of subjects.

\section{CRITICALITY AND TEACHING PRACTICES AT THE LWB}

Chun (2009, p. 182) claims that critical literacy is "an approach to reading and writing texts with the aims of questioning and challenging dominant representations of our society and its members". This quote offers us some guide to develop activities and teaching material - think about how groups are represented, how certain concepts are represented in the texts, for instance. However, as Chun (2009) points out, critical literacy approaches are not a "formulaic pedagogy blindly applied in any classroom" (p. 184), thus the idea is that teachers and students explore 
possibilities in their specific cultural and social contexts. In short, teachers have to be sensitive to the particularities of the various contexts in which they teach (KUMARAVADIVELU, 2001).

With this in mind, we now discuss some teaching proposals developed by the two last authors of this paper, under the supervision of the first one, in the context of LwB. The proposals tried to implement theoretical notions of critical EAP based on a dialogic perspective of language, and took place on the course Oral Production: Academic Presentations, whose objectives were to prepare students to create and deliver oral presentations in the academic context. We discuss the proposals by describing and analyzing the lesson plans and materials used in the courses as well as field notes collected by the teachers. For that we use a qualitative methodological approach, in which we are interested in developing "concepts, insights, and understandings from patterns in the data rather than collecting data to assess preconceived models, hypotheses, or theories" (TAYLOR; BODGAN; DEVAULT, 2016, p. 8). By doing so, we aim to better comprehend and thus improve our own practice.

Let us start with Jessica's experience.

\section{WHO HAS THE RIGHT TO SEE?}

Jessica's course was held at the Federal University of Uberlândia between September and November 2018, and it was developed for university students on the B2 level of the CEFR. Among students there were graduate and undergraduate people from different areas of study, but who were part of the same higher education institution. Although they were all placed on the B2 level, it was not a homogenous group, but this hardly ever caused any kind of miscommunication between themselves. All the classes were taught in the computer lab of the Linguistic and Literature Institute of the university, and each student would have access to a computer to do the activities proposed by the teacher.

In order to help students prepare, create and deliver oral presentations in the academic context, many activities were developed so as students could get more familiarized with the genre and its characteristics, such as the language features common to academic presentations, and by the end of the course be able to identify specific characteristics of the genre and apply to their presentations.

After a month or so developing activities related to academic oral language, presentation outline, time organization and other important aspects of academic presentation, we decided to bring activities aimed at exploring these presentation's aspects as ways of inclusion or exclusion of listeners. With this in mind, we developed a lesson plan in which the leading discussion was about accessibility and inclusion in oral presentations. The discussions were followed by activities on how to make presentations accessible for people with physical disabilities, such as visual or hearing impairments, or mental disorders that cause individuals to understand information in different ways and timing, such as the attention deficit hyperactivity disorder (ADHD).

The first step was to bring a discussion about what makes good presentations good, and for that we chose an article from the International Language Academy of Canada 
(ILAC) website called "10 Tips for Giving a Great Presentation in English"12. We divided students into three groups and assigned each group three or four tips that they then read and explained to the other groups. While the groups were explaining the tips, the other groups would make comments and share their opinions about the topic of discussion.

During the open discussion, the groups brought up aspects such as language, the speaker's preparation and the importance of understanding that you might not know who your audience is or what your audience knows about the topic. In terms of language, students pointed out that being able to be understood and communicate a message is the most important thing when you are delivering a presentation. With that said, being able to deliver a presentation to a heterogeneous audience using appropriate language is also something we discussed during the activity. For instance, many people that might not know the presentation's topic very well could be part of the audience, so should the speaker not create a space where they can contextualize the presentation they might not be understood.

Bakhtin (1935/1986 ) claims that when the listener perceives and understands the (linguistic) meaning of a discourse, they are able to give it an active response, such as agreeing or disagreeing. Besides, while producing a discourse, the objective of speakers is to somehow reach the interlocutors, so there is no point of producing a discourse if the interlocutor will not be able to respond. Bakhtin states that

\begin{abstract}
Any understanding of live speech, a live utterance, is inherently responsive, although the degree of this activity varies extremely. Any understanding is imbued with response and necessarily elicits it in one form or another: the listener becomes the speaker.. (...) And the speaker himself is oriented precisely toward such an actively responsive understanding. He does not expect passive understanding that, so to speak, only duplicates his own idea in someone else's mind. Rather, he expects response, agreement, sympathy, objection, execution, and so forth. (BAKHTIN, 1935/1986, p. 68-69)
\end{abstract}

With that said, we believe that understanding a discourse goes beyond only decodifying words, it is directly related to the interlocutor's ability to connect with what is being said. Therefore, when an audience cannot relate to a presentation there will not be any active response or any kind of response whatsoever, so it becomes pointless for the locutor to convey that message. As speakers, we want to be heard and understood, we want people to react to what we are saying, and since our discourse "is a bridge thrown between myself and another. If one end depends on me, then the other depends on my addressee." (VOLOŠINOV, 1929/1973, p. 86). It might be impossible to do such a thing during an oral presentation when speakers and listeners do not share common background information.

The discussion about language and background information in oral presentations gave students the opportunity to be aware of and discuss how these two aspects play such important roles when delivering a presentation. The groups commented on how

12 Available on https://www.ilac.com/tips-for-giving-a-great-presentation-in-english/ Access July, 7th, 2020. 
adapting the language and providing background information about the presentation's topic might make it easier for listeners to understand it, as well as why these are aspects to consider if a presentation is good or bad.

For the second part of the activity, we asked students two questions, "What is accessibility?", and "How is accessibility related to oral presentations?", and gave them some time to discuss with their peers. After some discussion, students shared their thoughts on the questions and pointed out important things about the lack of inclusion during oral presentations. For example, how speakers usually do not take that into consideration during an oral presentation there may be listeners among the audience that might not enjoy the presentation, or learn anything whatsoever, because the presentation was not designed to meet these listeners' necessities.

In order to extend the discussion, we used an article from the Web Accessibility Initiative (WAI) website called "How to Make Your Presentations Accessible to All", ${ }^{13}$ which gives tips on how to develop and deliver more accessible oral presentations in terms of language, visual aids, organization, etc. There were many suggestions on the article, not only for speakers but also for organizers to develop more inclusive events. From the nine tips given, we chose six to be used during the class which can be checked in Fig. 2.

Fig. 2

\title{
How to Make Your Presentations Accessible to All
}

\begin{abstract}
Do you remember a time when people around you broke out in laughter, but you didn't hear the joke? Be careful not to leave out information for some people in your audience. For example, if you say "you can read it on the slide", you are probably excluding people who cannot see the slide.
\end{abstract}

Summary

This page helps you make your presentations, talks, meetings, and training accessible to all of your potential audience, including people with disabilities and others. Inclusive presentations have many benefits.

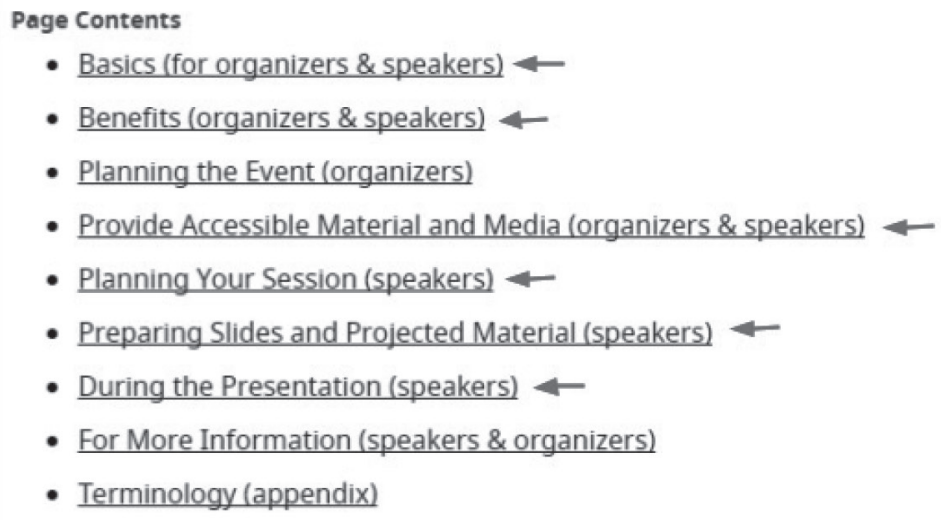

Source: https://www.w3.org/WAl/teach-advocate/accessible-presentations/

13 Available on https://www.ilac.com/tips-for-giving-a-great-presentation-in-english/ Access July, 7th, 2020. 
We then assigned two different tips for each of the three groups and asked them to do the same thing they did with the previous activity: read and explain it to the other groups. While the groups were explaining the tips, we would brainstorm with the class ways of putting that suggestion in practice and asking questions to encourage the discussions.

Overall, the suggestions were very easy and feasible considering the complexity of the problem, from giving listeners a break so they can clear their minds or do necessary things, such as take insulin, to changing the way language is used during the presentation. The article points out that visual materials and language need to be carefully thought through so the speaker does not leave anyone out of the presentation. For example, in order to include people with visual impairments, the speaker could describe all visual information, because when they say things like "You can see the picture on the slide" or "The results I found are represented on this graphic" people with visual impairments are not able to follow. This also happens when speakers show a video without subtitles and exclude people with hearing impairments, who are also excluded when speakers do not put essential information on the visual materials (slides, images, videos, board, etc.) and rely only on speaking.

Therefore, we noticed again that language is very important for an inclusive environment, not only to create a common ground for speaker and listeners as we already discussed, but also to include people with different necessities by using inclusive language. Therefore, we believe that language is a very powerful resource, and using it requires constant critical thinking to understand the implications of what we say and how we say it, as well as how it affects others around us. As language teachers, we share the responsibility to create spaces where students can discuss language under a critical perspective. It is very important to give students the opportunity to rethink the language they use so they can maybe transform their experience as English speakers.

The whole point of this specific discussion was to create an opportunity for students to learn and share their ideas on accessibility and how this could be somehow related to delivering presentations, as well as rethink and improve their practice as presenters/lecturers. During the discussion, students shared that they have never thought about lack of accessibility as a problem in this context, and how simple things can be done to include different audiences with different needs. The response we had from students was very important for the development of the other steps of this activity. They were engaged and willing to find ways to become more inclusive during their oral presentations.

For the third part of the activity, we asked the groups to make a list of aspects they considered important to develop and deliver oral presentations. After a brainstorming with all groups' lists and considerations, we came up with a list of seven main questions (Table 1) to serve as criteria when evaluating oral presentations: 
Table 1. Presentation Rubric.

\begin{tabular}{c|r}
\hline 1. & Is it well organized? (Does it have an introduction, a development and a conclusion?) \\
\hline 2. & Is it coherent? (Does it have a logical reasoning? Do the ideas match?); \\
\hline 3. & $\begin{array}{r}\text { Is it catching? (Is the presentation easy to follow? Is it catching the listeners' attention? Does the speaker use } \\
\text { visual aids to help listeners understand the topic in discussion?) }\end{array}$ \\
\hline 4. & $\begin{array}{r}\text { Is the language appropriate? (Is the speaker being clear? Is the language adequate to the audience? Is the } \\
\text { speaker using body language and language features, such as linking words, to help listeners understanding?) }\end{array}$ \\
\hline 5. & Was the time respected? \\
\hline 6. & $\begin{array}{r}\text { Is the person prepared to talk about that? (Does the speaker master the topic? Is the speaker prepared to } \\
\text { answer questions about the presentation?) }\end{array}$ \\
\hline 7. & $\begin{array}{r}\text { Is the presentation accessible to different audiences? (Does the speaker take into consideration that there } \\
\text { might be different audiences with different needs attending to the presentation? Does the speaker use visual } \\
\text { and language aids to help the audience follow the presentation?) }\end{array}$ \\
\hline
\end{tabular}

Source: The authors.

After creating this list, we started the fourth part of the activity in which students entered the Youtube channel "Yale Courses"14 and chose a lecture of their interest to analyze using the criteria we established. All the lectures from this channel are part of real courses that take place at Yale University, so they were given by professors of the university in a real class that was part of a syllabus, made for students of the university's programs, and recorded to be available online for anyone who might be interested. They were supposed to watch parts of the lecture and take notes on how the speaker delivered the presentation based on the criteria we established together. Then, they would share with their peers and teacher the results of the analysis, and suggest some points that could be improved as well as how the speaker could have made such improvements.

While sharing their notes with the class, most students said that criteria concerning the speaker's knowledge, time, and coherence were met, since the speakers are specialists in the field and were very prepared to talk about the topic. However, when it came to language use, some students had some criticisms concerning body language and how most teachers did not explore body language as an asset to help with the presentation. On the other hand, when it came to spoken language, students said that the language was appropriate since the presentation was aimed at students enrolled in the university's programs.

Overall, students shared that they did not find the presentations accessible. They gave some examples such as how some teachers would crowd the slides in a way that it became very confusing to understand, and others would not even have slides to support the presentation. While pointing out these aspects, they were discussing how this could affect people with different needs. For example, a deaf person might not be able to follow a presentation without slides or with overcrowded slides, the same way that maybe someone with dyslexia could have a hard time trying to take notes or understand the information provided by the slides. In conclusion, the students could see that the lecturers were very prepared to deliver the presentation, but at the same

14 Available on https://www.youtube.com/user/YaleCourses/featured Access July, 7th, 2020. 
time they were not careful enough to think about their listeners as part of a (possibly) heterogeneous audience.

Along with this discussion, students started comparing what they saw on the videos with classes they had (and still have) during their own programs at the university. Students would bring personal and real examples of professors they had that would do exactly the same thing as the speakers from the videos. They commented on how sometimes it was difficult for them to follow a class without slides, appropriate language, visual aids, etc., and how difficult it might be for someone with any kind of impairment to succeed in an academic environment that does not always include them.

For the next part of the activity, students were asked to develop and deliver an oral presentation about their undergraduate program covering basic topics, such as the entrance exam, duration of the program, the syllabus organization, and also information about internship and career options. Moreover, students were expected to develop presentations that were accessible to different audiences. The topic of the presentation was based on an event that the university holds yearly, usually in October or November, called "Come to UFU". During the event, the university's institutes prepare stands and lectures about the undergraduate programs that are visited mainly by high school students of the region; therefore, potential students of the university in the future.

Since in that group there were not any students with physical disabilities that could jeopardize their access to information during a presentation or any kind of psychological disorders that affect cognitive responses whatsoever, it was proposed that during each presentation there would be one listener using a blindfold and one listener with headphones listening to instrumental music. The student using the blindfold was representing someone with vision impairment and the student using the headphones was representing someone with hearing impairment. The objective was to create a simulation where two people from the audience had an impairment that would require the speaker to use visual aids (such as slides, pictures, graphics), and language aids (such as linking words and descriptive language) to reach these listeners. Students took turns during the presentations, so by the end of the activity all of them had had the experience of using the blindfold and the headphones.

The whole point of the blindfold and the headphones was to put students in a position that was not comfortable for them, since everybody there could listen and see well. By using the accessories, they would not be able to use one of the five senses they have, which made them struggle as an audience. All things considered, it is important to understand that we do not think this activity is the perfect portray of having a diverse audience. In an ideal situation we would have students to present with a big audience with different listeners, but unfortunately we had to create, within our resources, a context that was not ideal but it was the closest to it that we could get at the time.

It is impossible for those who listen and see well, to imagine the constant struggle of people who have hearing or visual impairments. However, we believe that it is extremely important for individuals to acknowledge their privileges and try to understand what the implications of this in one's life are.

hooks (2010) believes that critically thinking about any topic "involves first discovering the who, what, when, where, and how of things (...) and then utilizing that 
knowledge in a manner that enables you to determine what matters most." (hooks, 2010). On that premise, we totally agree with hooks because she is stating that for individuals to critically think about anything, they have to understand it before taking a stand. Therefore, using the blindfold and the headphones during the presentation was the alternative we had to try to create another space where students would minimally perceive things under the perspective of not being privileged.

Besides delivering the presentations, students also evaluated each other's presentations, along with the teacher, using the criteria established. To do that, we used a Google sheets document and every time someone finished presenting, we, listeners, would anonymously comment on the document under the speaker's name. The comments served as feedback for the speakers, so listeners were oriented to write them by not only giving suggestions of improvement but also pointing out the strongest points of the presentation.

During this evaluation activity, students made really nice comments on each other's presentations. For example, some students pointed out that the color and font of the speaker's slides made it harder to understand the content, and suggested the speaker should use contrasting colors, and a different (or bigger) font. Students would also comment on how the speaker could have made a better introduction by giving the audience more background information, and they missed this introduction and felt a little bit lost during the presentation because of that. Besides the constructive criticism, students pointed out many strong aspects of the speaker's presentation, such as how the speaker used a simple language that everybody was able to understand and gave real life examples to illustrate something very specific or too theoretical from their area.

In order to make more specific comments about accessibility, besides giving the overall feedback to speakers anonymously, we asked the student with the blindfold and the one with headphones to share their experiences and the struggles they had during the presentation.

The students that used the blindfold mentioned things such as how hard it was to follow the presentation when the speaker would say things such as "here in this picture" or "here in the slide" and did not describe the picture or the slide's contents. They also mentioned that other noises, such as parallel conversation or cell phone vibration, would distract them from the presentation. According to them, when the speaker was careful enough to describe the slides and images, as well as use linking words and expressions such as "after that", "however", "on the other hand", "first", "next", etc., it was easier for them to understand the presentation's content and its outline.

The students that used the headphones also contributed a lot by sharing their experiences. They mentioned that it was impossible to follow the presentation when there was not enough information on the slides. On the other hand, if the slides were overcrowded, covering too much information, they would not have enough time to read it and ended up getting lost anyway. Therefore, they suggested speakers should put essential information on the slides and explore visual aids, such as images, gifs, etc. because these materials could summarize the content in a more visual way and, consequently, it would be easier for them to understand the content.

With that said, it is important to say that we were not trying to have perfect presentations from our students at the end of this activity, and the fact that there were 
many things for them to improve in their presentations did not bother us in any way or made us think that the activity was a failure. In one of her most incredible works, Teaching critical thinking: practical wisdom, bell hooks (2010) claims that "when everyone in the classroom, teacher and students, recognizes that they are responsible for creating a learning community together, learning is at its most meaningful and useful. In such a community of learning there is no failure." (hooks, 2010, p. 11). Our main goal with this activity was to collectively create a discussion about academic presentations beyond its specific structure or language. By giving the discussion a social, historical, and critical perspective that considers subjects part of the process of creating and delivering academic presentations, we met our major and minor goals and finished the activity with great reflections and many positive results.

As a consequence, we could notice some great changes in students' presentation in comparison to the presentations they delivered before the discussions of this activity. For instance, before the students did not necessarily feel the need to use slides to deliver a presentation, but for this final presentation they all created slides. It is important to say that the slides were very good and most of them could cover the essential pieces of information. Besides, it was clear that students were way more careful with language than before. During this activity, we could see students using more linking words and descriptive language than before. They were careful enough to describe images and announce when they were going to the next slide or going back to the previous one. Moreover, we noticed that students were more worried about the audience's understanding, they would make pauses to check understanding and open for questions whenever it was necessary.

In a nutshell, the idea was to first start a discussion on accessibility then give students the opportunity to think about their presentations from a different perspective. As a result of that, we had great presentations with speakers that were able to rethink the way they used to deliver presentations and transform what might once have been an excluding presentation and turned out to be a presentation that included different audiences by making simple changes such as the color of slides, font size or the use of transitional words. With that said, it is very important for us to mention that this lesson would not be possible if it was not for students' participation, working together to exchange ideas and develop the activity with us.

Shall we discuss now teacher Lucas's experience.

\section{WHO HAS THE RIGHT TO SPEAK?}

Lucas's course was also 32-hour long and was developed for students on the B2 level of the CEFR and happened between March and May of 2019 at the Federal University of Uberlândia. There was an attendance of around 9 people, among which were undergraduate and graduate students from different programs, as well as one professor, all of the same university. We met 2 times per week and each class had a duration of 2 hours.

The purpose of this course was to prepare students to produce and deliver their own presentations. So at the end of the course, they would be able to identify, analyze, and discuss the characteristics of academic presentations and other issues related 
to this genre. As well as be able to apply, with the appropriate adaptations to their specific contexts, what was developed throughout the lessons.

In order to achieve these objectives, the lessons had moments of pair and group work in which the students were asked to talk about what they already knew about the content, then work with an example, create their own productions, review them, and help each other with feedback. And even though the course's emphasis was on oral production, it also integrated other abilities. So all the process mentioned above was, in fact, a series of pedagogical activities that required and promoted the use of combinations of different skills at given times.

The first activity of the course dealt with the students' ideas of what is required of a presentation to be considered good, what would be the challenges involved in it, and if there were other challenges when the delivery of the presentation was in a foreign language. After discussing these questions the students worked with some vocabulary present in a video they would watch in the sequence.

The video chosen was a talk in which the speaker reports his struggles as someone that speaks English with a Pakistani accent and, even though he received hostile comments over his accent, he still uses his voice as an instrument of work. As the students' watched the video they had the question "What is at stake in the situation described by the speaker?", which prompted a discussion right after they watched the video.

As the students were discussing, they dealt with issues such as: "Is there a problem in speaking with an accent?"; "everyone has an accent"; and "why are some accents prestigious and others aren't?". In this way, the students could question the power relations, which are intrinsically linked to interactions among and within languages.

This questioning has a lot to do with the first question proposed to the students "what makes a presentation to be considered good?". The conception of a "good presentation in English" is closely related to the student's notions of an ideal English speaker, who would be someone that is native of hegemonic countries and speaks a homogeneous and therefore "perfect" variety of the language.

These standards are not particular to the students of this course, they were built as the result of years of erasure and consequently delegitimization of language varieties there were not from the groups that held political and economic power. For this reason, it is not uncommon for English teachers to face students' resistance and even refusal when a less prestigious variety of the language is brought to the classroom.

Hashiguti (2017) claims that the difficulty some Brazilian students face to speak English as a foreign language regards the history of language policies. Based on Spivak's reflections, she argues that

Especially for cases like Brazil, which was colonized by Portugal and not by an English speaking country, English really has the quality and the mark of a foreign language. Speaking it revolves interdictions and taboos and means trying to occupy and dominate a new territory - a practice that postcolonial countries with silencing linguistic histories like Brazil do not know up to now. Although rooted in the body, learning to speak a foreign language is not the mere result of 
physical and intellectual capacities; it is also an issue closely related to a memory of (learning) languages and founding economic, political and social conditions of a nation, with its injunctions. It is a subjective movement to leave the place of the silenced subordinate. It is certainly not a simple movement, especially when there is a postcolonial heritage and a subaltern frame which dominates and organizes the various forms of activities and thoughts. I can't speak English., and the actual silencing of spoken EFL as its metaphor in discourse, is a statement that can only emerge because a place and a voice to speak still have to be constructed. (HASHIGUTI, 2017, p. 228)

In this particular example we are exploring, the student's reactions were not different, most of them showed to be uncomfortable with the way the presenter spoke. So the activity that followed the discussion, analyzed other aspects of the presentation, such as the levels of politeness and formality. These analyses showed that despite the fact that the presenter did not meet their expectations of an ideal speaker, he still delivered a good presentation.

This conclusion is of an extreme importance for our context of EAP because it makes clear that mimicking an ideal speaker is not enough to reach the goal of delivering a high-quality presentation in English. And it also allows and empowers students to unapologetically speak with their accents. Thus, normalizing the fact that a non-native speaker of English can be the one in a position of power, able to produce and share knowledge.

Then, the following activities proposed the creation of short presentations on what is considered to be normal and abnormal in different parts of our society. The students were divided into groups and received a list of possible topics. After deciding the topic, each group had time to expose, discuss, and debate their views and plan the presentation. The presentations showed that the students had understood what it means to be critical and that the concept of (ab)normality can be relative.

To conclude this sequence of activities each student received a self-assessment sheet in which they had to point out what went well in their presentation, what could be improved, and what to do in order to improve it. And their notes revealed that, even though speaking accurately was still being desirable, sounding like a native speaker was not a concern. They were, in fact, worried about the development of other skills, such as time management, body language, dealing with nervousness, and content quality.

Therefore the proposed activities not only aimed to help students to develop the so-called four language skills, nor had the single objective of offering strategies to excel tasks required in target-situations. But they also intended to foster criticality in order to raise students' awareness of their own perceptual filters that pervade each and every interaction in any language. So they could make more conscious and well-reasoned decisions on and through language.

Hence, the material used in this course was intentionally selected due to their diversity (taking into consideration what is mainstream in English language classrooms). And, consequently, their potential capacity of arousing feelings of strangeness, which is key to the process of becoming critically literate. 


\section{FINAL WORDS}

In this paper we tried to shed light to some possible ways to explore critical EAP, by discussing teaching proposals developed by pre-service language teachers participating in the LwB Program. The proposals attempted to point out that criticality goes beyond proposing discussions on tabu topics once language and all kinds of human activities are connected (BAKHTIN, 1997). Therefore, when we develop a sequence of activities that is filled with discussions about language in academic presentations and how language can change the way people perceive our speech, we give students the opportunity to put at stake the way they have been delivering presentations and transform themselves as English speakers.

More than that, we also collectively created a space to think about our privileges, and the place we occupy in society, as well as minimally try to understand the place the less privileged ones have in the exact same society. In order to have a transformative pedagogy (hooks, 1994), we teachers aim to create a classroom where students feel responsible to contribute to a democratic environment not only by understanding certain patterns and inequalities, but also by promoting actions that try to make this privilege gap smaller.

In this sense, our analyses point to the need to carefully consider the teacher's role in the process of developing a more critical perspective toward EAP as they are the ones who are inside the classroom making things happen. Teachers are the ones who implement notions of language, of what it means to learn a language, of what English is.

Morgan (2009) says that teachers in EAP have been seen as mere technicians, thus considered as facilitators rather than contributors or creators of disciplinary knowledge. By discussing some teaching proposals developed by the authors of this paper, we tried to resist such view by occupying the place of transformative practitioners, which are "aware of the larger socio-political and economic conditions (e.g. globalization, neoliberalism) that shape educational agendas, academic rules and curricula, and the disciplinary content students are required to learn" (MORGAN, 2009, p. 88-89).

Another important thing to mention is that critical EAP is not about promoting pedagogies of despair or pessimism, as Morgan (2009) also points out. It's not about imposing a teacher's political agenda, discussing only polemical issues neither is it about ignoring academic requirements. Instead, critical EAP can be seen through what Cadman (2005) calls 'pedagogy of connection' - which is about establishing a comfortable or a hospitable classroom environment, a place where students do want to be and want to connect to the others while learning the language. Benesch (2009) claims that critical EAP can be seen as hopeful praxis as "critical teaching is not intended to mine the world for problems which are then presented to students as hot topics for debate" (BENESCH, 2009, p. 84).

In our view, the discussion of teaching EAP from critical perspectives contemplates the idea of questioning what seems obvious, considering power relations and the non neutrality of any communicative event. In other words, for the critical to happen, there must be some actual dissociation from one's available explanatory texts and discourses - a denaturalization and discomfort and "making the familiar strange" (LUKE, 2004 apud BENESCH, 2009, p. 82). 
We would say that critical EAP understands the classroom as a space for heterogeneity, diversity, subjectivity. It sees the classroom as a place of conflict, a site of struggle as it considers that the process of meaning making is produced through power relations brought by class, race, gender, nationality, age among others. The social identities of teacher and students are thus taken into account. That is why we are interested in investigating who has the right to speak and be heard in academic environments, for instance. It also takes into account the sociopolitical context of teaching and learning a foreign language. That is why we are interested in investigating what 'teaching EAP in Brazil' means. 


\section{REFERENCES}

BAKHTIN, M. M. (c. 1935/1986). Speech Genres and Other Late Essays. (V. W. McGee, Trans.). Austin: University of Texas Press.

BENESCH, S. (1999). Rights Analysis: Studying Power Relations in an Academic Setting. English for Specific Purposes, 18 (4), 313-327.

BENESCH, S. (2001). Critical English for academic purposes: theory, politics, and practice. Mahwah, NJ: Lawrence Erlbaum Associates.

BENESCH, S. (2006). Critical Media Awareness: Teaching Resistance to Interpellation. In: EDGE, J. (ed.). (Re-)locating TESOL in an age of empire. Great Britain: Palgrave Macmillan. p. 49-64.

BENESCH, S. (2009). Theorizing and practicing critical English for academic purposes. Journal of English for Academic Purposes, 8, 81-85.

BRITO, C. C. P.; CÓRDULA, M. S. M. Desenvolvimento profissional na formaçâo do professor de línguas: IsF como espaço de residência pedagógica. Revista do GEL, v. 17, n. 1, p. 29-49, 2020.

CADMAN, K. (2002). English for Academic Possibilities: the research proposal as a contested site in postgraduate genre pedagogy. Journal of English for Academic Purposes, $1,85-104$.

CADMAN, K. (2005). Towards a 'pedagogy of connection' in critical research educatio: a REAL story. English for Specific Purposes, 4, 353-367.

CHUN, C. W. (2009). Contesting neoliberal discourses in EAP: critical praxis in an IEP classroom. Journal of English for Academic Purposes, 8, 111-120.

CHUN, C. W. (2017) Critical literacy writing in ESP: perspectives and approaches. In: FLOWERDEW, J.; COSTLEY, T. (eds.). Discipline-specific writing: theory into practice. New York: Routledge, p. 181-195.

EDGE, J. (ed.). (2006). (Re-)locating TESOL in an age of empire. Great Britain: Palgrave Macmillan.

FREIRE, Paulo. (1970/2005) Pedagogy of the Oppressed, 30th anniversary edn, trans. Myra Bergan Ramos (New York, Continuum).

HARWOOD, N., \& HADLEY, G. (2004). Demystifying institutional practices: critical pragmatism and teaching of academic writing. English for Specific Purposes, 23, 355-377.

HASHIGUTI, S. T. (2017). Can we speak English? Reflections on the unspoken EFL in Brazil. Trabalhos em Linguística Aplicada, v. 56, n.1, p. 213-233, 2017.

HELMER, K. A. (2013). Critical English for academic purposes: building on learner, teacher, and program strengths. Journal of English for Academic Purposes, 12, 273-287.

HOOKS, Bell. (1994) Teaching to transgress: education as the practice of freedom. New York: Routledge.

HOOKS, B. (2010) Teaching critical thinking: Practical wisdom. New York: Routledge. 
KUMARAVADIVELU, B. (2001). Toward a Postmethod Pedagogy. TESOL Quarterly, 35, 537-560.

MORGAN, B. (2009). Fostering transformative practitioners for critical EAP: possibilities and challenges. Journal of English for Academic Purposes, 8, 86-99.

NOBLE, S. U. Algorithms of Oppression: How Search Engines Reinforce Racism. New York: New York University Press, 2018.

PENNYCOOK, A. (1994). Beyond (F)utilitarianism: English "as" academic purpose. Hong Kong papers in linguistics and language teaching, 17, 13-23.

STARFIELD, S. Critical perspectives on ESP. In: PALTRIDGE, B.; STARFIELD, S. (Eds). The Handbook of English for Specific Purposes. Wiley-Blackwell, Malden, MA, USA, 2013. p. $461-479$.

TAYLOR, S. J.; BOGDAN, R; DEVAULT, M. L. Introduction to qualitative research methods: a guidebook and resource. 4th ed. New Jersey: Wiley, 2016.

VOLOŠINOV, V. N. (1929/1973). Marxism and the Philosophy of Language. Translated by MATEJKA, L; TITUNIK, I.R. - New York, London - Seminar Press. 